\title{
The Determinant of Employee Engagement
}

\author{
Siswanto \\ Faculty of Economics, State Islamic University,Maulana Malik Ibrahim Malang \\ Email: siswanto@pbs.uin-malang.ac.id \\ Ajeng Ekowati Lestari \\ Faculty of Economics, State Islamic University,Maulana Malik Ibrahim Malang \\ Email: el_ajeng@yahoo.com
}

\begin{abstract}
Abstrak:
Employee engagement is a significant work attitude to reach the organization's goal. The employee engagement includes improving the employees' responsibilities, motivating the coworkers, and influencing the employees' performance. Accordingly, a study in line with the determinant of employee engagement is needed. The purpose of this study is to analyze the determinant of employee engagement. This study used quantitative approach. The samples of this research were 187 employees of manufacturing company in Mojokerto city. Data retrieval used a questionnaire. The sampling technique used proportional random sampling. Data analysis used path analysis. The result of the study showed that financial compensataion and job satisfaction were determinant of employee engagement. The financial compensation and job satisfaction improve the employee engagement. Whereas, the nonfinancial compensation does not influence the employee engagement.

[Employee engagement merupakan salah satu sikap kerja yang penting untuk mencapai tujuan organisasi. Employee engagement dapat meningkatkan tanggung jawab karyawan, memotivasi rekan kerja dan mempengaruhi kinerja karyawan. Oleh karena itu, studi tentang determinan employee engagement diperlukan. Tujuan penelitian ini adalah menganalisis determinan employee engagement. Penelitian ini menggunakan pendekatan kuantitatif. Jumlah sample sebanyak 187 karyawan perusahaan manufaktur di Kota Mojokerto. Pengambilan data melalui kuesioner. Sedangkan, teknik pengambilannya menggunakan proporsional random sampling. Analisis data menggunakan analisis jalur. Hasil penelitian menunjukkan determinan employee engagement adalah kompenansial finansial dan kepuasan kerja. Kompensasi finansial dan kepuasan kepuasan kepuasan kerja meningkatkan employee engagement. Sedangkan, kompensasi non finansial tidak berpengaruh terhadap employee engagement.]
\end{abstract}

Kata Kunci: Karyawan; Kompensasi; Finansial; Kepuasan Kerja. 


\section{INTRODUCTION}

Employees have a significant role in achieving the organization's goal. Sui Hai Juan dkk., ${ }^{1}$ stated that employees are the valuable assets of an organization. They who have emotional attachment with the organization values will improve the performances of employees and the organization. The emotional attachment to the organization values is called employee engagement. J. Anitha, ${ }^{2}$ showed that commitment levels and employee involvement in an organization and its values or generally referred to a concept of employee engagement will improve the performance of employees. While Matthew P. Gonring ${ }^{3}$ showed that employee engagement will improve the performance of organization. Employee engagement also change the service orientation of employees. Sapna Popli dan Irfan A Rizvi, 4 showed that employee engagement is a strong predictor to customer service orientation. Yet, Johnson, Cattermole, and Jackson, ${ }^{5}$ showed that employee engagement implementation enhances the success of an organization.

Employee engagement is influenced by compensation. Sutrisno, ${ }^{6}$ stated that compensation will make comfortable for employees in working and having initiatives. Federman ${ }^{7}$ stated that one of employee engagement motivators is incentive and appreciation. Briananta Winda Kurniawan dan Harlina Nurtjahjanti ${ }^{8}$ showed that financial and nonfinancial compensations have positive outcomes to employee engagement.

A familiar method used to improve the working cycle quality is to create the emotionally employee arrangement to their company or organization. Linda Holbeche and Geoffrey $^{9}$ explained that individual relationship with organizations create employee engagement that is characterized as a feeling of commitment, enthusiasm and energy that are intended to reach higher levels of even the most difficult tasks, exceeding expectations, and taking initiatives to help organizations in achieving their goals. Emotional employee attachment is called the employee engagement.

A company must be able to build the employee engagement to the company because they have a high sense of responsibility for their works and a high enthusiasm to achieve company goals. Thus, without any coercion, an employee, with his initiative, will try to develop himself, be responsible for his work, try to contribute ideas to the development of the company, be innovative, and have a high sense of loyalty towards the company. In enhancing the employee engagement, the company has to consider its employee welfare. It is influenced by some factors, such as compensation.

\footnotetext{
${ }^{1}$ Sui Hai Juan dkk., "KNOWLEDGE MANAGEMENT AND EMPLOYEE ENGAGEMENT," HAPPY READING, 2019.

2 J. Anitha, "Determinants of employee engagement and their impact on employee performance," International journal of productivity and performance management 63, no. 3 (2014): 308.

3 Matthew P. Gonring, "Customer loyalty and employee engagement: an alignment for value," Journal of Business Strategy 29, no. 4 (2008): 29-40.

4 Sapna Popli dan Irfan A Rizvi, "Exploring the relationship between service orientation, employee engagement and perceived leadership style: a study of managers in the private service sector organizations in India," Journal of Services Marketing 29, no. 1 (23 Januari 2015): 59-70, https://doi.org/10.1108/JSM-06-2013-0151.

5 Jaime Johnson, Gary Cattermole, dan Diane Jackson, "Employee engagement creates a brighter economic future at Jupiter Hotels," Strategic HR Review 13, no. 2 (4 Februari 2014): 81-85, https://doi.org/10.1108/SHR-11-20130110.

6 Sutrisno, E. Manajemen Sumber Daya Manusia. (Jakarta: Kencana, 2012), 190.

7 Federman, B. Employee Engagement: A Road For Creating Profits, Optimizing Perfomance, And Increasing Loyalty. SanFransisco: Jossey Bass, 2009,44

8 Briananta Winda Kurniawan dan Harlina Nurtjahjanti, "Hubungan Antara Persepsi Terhadap Kompensasi Dengan Employee Engagement Pada Karyawan PT. X," Empati 5, no. 4 (2017): 732-737.

9 Linda Holbeche dan Geoffrey Matthews, Engaged: unleashing your organization's potential through employee engagement (John Wiley \& Sons, 2012).
} 
Besides compensation, employee engagement is also affected by employee job satisfaction. Veithzal Rivai ${ }^{10}$ defined that job satisfaction is an evaluation expressing the levels of pleasure and satisfaction of someone at work. A manager of a company must find out the employees' satisfaction level. High employee satisfaction improves the employee engagement to their company. This study was conducted by Donata Asmarata Manik ${ }^{11}$ and Andi Kari12 about the effect of job satisfaction on employee engagement gives a significant effect. Basically, the individual job satisfaction levels are different. The benchmark of employee job satisfaction is an assessment of the suitability of the level of service expectation provided by the company to employees for the reciprocation of services that have been provided by employees to the company. In increasing employee satisfaction, companies need to pay attention to employee needs, one of which is the provision of compensation. This is verified by the opinion conveyed by Sutrisno ${ }^{13}$ which explained that one of the factors that influence job satisfaction is the financial factor.

Compensation can enhance job satisfaction. Ikmal Nur Muflih ${ }^{14}$, Mia Siti Fauzia15, and Althisa Paramartha ${ }^{16}$ showed that compensation has a positive and significant effect on job satisfaction. Furthermore, Nisa Ayu Wulandari ${ }^{17}$ showed that compensation variable has a significant effect on employee engagement. Meanwhile, A.M. Harry 18 showed that compensation has no effect on employee engagement. Compensation is not a very important thing to survive in an institution and the compensation obtained is often not a problem, but also cannot guarantee employee engagement. The study case of the study was a manufacturing company in Mojokerto, East Java, Indonesia. This manufacturing company strives to provide good service to consumers by creating quality products. To create goals, this company needs employees who are bound to the company. During the process of recruitment interview, many prospective employee wanted to work in the company because the financial compensation provided was quite promising compared to other manufacturing companies in Mojokerto. In addition, many employees prefer to stay in the company for the same reason. So, financial compensation makes employees stay in the company. This study does not only look at the effect of financial compensation, but also the effect of non-financial compensation on employee engagement.

10 Veithzal Rivai. Manajemen Sumber Daya Manusia untuk Perusahaan. (Jakarta: RajaGrafindo Persada, 2004), 478.

11 DONATA ASMARANTA Manik, "Pengaruh kualitas kehidupan kerja (quality of work life) dan kepuasan kerja terhadap keterikatan karyawan (employee engagement) di PT," Telekomunikasi Indonesia Tbk Witel Kalbar. Skripsi, tidak diterbitkan, Universitas Atma Jaya, Yogyakarta, 2015.

12 Andi Kari, "Pengaruh Kepuasan dan Motivasi Kerja terhadap Engagement Pegawai Tenaga Kependidikan di Politeknik Negeri Bandung” (PhD Thesis, Universitas Pendidikan Indonesia, 2013).

13 Sutrisno, E. Manajemen Sumber Daya Manusia. (Jakarta: Kencana, 2012), 280

14 Ikmal Nur Muflih, "Pengaruh Kompensasi Dan Motivasi Kerja Terhadap Kepuasan Kerja Karyawan Pt. Aseli Dagadu Djokdja," Universitas Negeri Yogyakarta. Skripsi, 2015.

15 Mia Siti Fauzia, "PENGARUH KOMPENSASI TERHADAP KEPUASAN KERJA PEGAWAI (Studi Persepsional Pegawai di PT. PLN (Persero) Kantor Distribusi Jawa Barat dan Banten)" (PhD Thesis, Universitas Pendidikan Indonesia, 2015).

16 Althisa Paramartha, "PENGARUH KOMPENSASI TERHADAP KEPUASAN KERJA KARYAWAN PADA PT GALAMEDIA BANDUNG PERKASA," 2013.

17 Nisa Ayu Wulandari, "Pengaruh Kepemimpinan, Budaya Organisasi dan Kompensasi terhadap Keterikatan Karyawan (Studi Kasus Pada Bank Syariah Mandiri)" (B.S. thesis, Jakarta: Fakultas Ekonomi dan Bisnis UIN Syarif Hidayatullah Jakarta, t.t.).

18 A. M. Harry, "Pengaruh Kompensasi, Status/Pengakuan, dan Kesempatan Berkembang terhadap Tingkat Employee Engagement pada Karyawan Universitas Sanata Dharma" (PhD Thesis, Thesis Manajemen. Yogyakarta: Universitas Atmajaya, 2014). 


\section{LITERATURE REVIEW}

Compensation is an appreciation given by the organization to employees as a remuneration for their contributions to the organization ${ }^{19}$. Meanwhile, Mondy ${ }^{20}$ described compensation is a reward received by employees from an organization or company as a substitute for the services they have provided to. Compensation based on its acceptance can be divided into two types, namely financial and non-financial compensation ${ }^{21}$. Financial compensation in form of things paid by organizations or companies as salaries or wages, bonuses, premiums, medication, insurance, and so forth. While non-financial compensation is a non-financial compensation that can be in the form of the implementation of service programs for employees to create pleasant working conditions and environments, such as tourism programs, provision of places of worship in the workplace, provision of facilities.

Job satisfaction as an emotional condition of employees in the form of pleasant or unpleasant feelings in seeing the work they do ${ }^{22}$. Vetithzal Rivai, ${ }^{23}$ conveyed several wellknown job satisfaction theories, namely discrepancy theory, equity theory, and two factor theory. According to Moh. As'ad ${ }^{24}$ there are factors that influence job satisfaction, namely psychological factors, social factors, physical factors, and financial factors.

Employee engagement as the members of the organization, they lead their working roles and express themselves physically, cognitively, and emotionally during the work ${ }^{25}$. According to Cook, ${ }^{26}$ employee engagement is a enthusiasm and energy of the employees used to provide the best for the organization to serve customers. Hewit, ${ }^{27}$ stated that The Aon Hewitt Engagement Model explained that there are three characteristics, namely say, satay, and strive. Garber, ${ }^{28}$ said that there are 10 key factors for employee engagement namely commitment, attitude, alignment, communication, goals, buyer focus, commitment at work, loyalty, involvement, and ownership. Decision Wise, ${ }^{29}$ stated that the attachment can be described as a convergence of three factors, namely satisfaction, motivation, and effectivity.

\section{Compensation, Employee Engagement, and Job Satisfaction}

Incentives and compensation drive employee engagement. Federman, 30 said that one of the drivers of employee engagement is incentives and recognition. They are part of financial and non-financial compensation. Thomas, ${ }^{31}$ expressed his opinion if organizations only want compliance with workers, then they buy it with money and other tangible benefits.

\footnotetext{
19 Mutiara S. Panggabean. Manajemen Sumber Daya Indonesia. (Jakarta: Ghalia Indonesia, 2004), 75.

20 R. Wayne Mondy. Manajemen Sumber Daya Manusia Strategik. (Jakarta: Erlangga, 2008),4.

21 Triton, P.,B. Mengelola Sumber Daya Manusia. (Yogyakarta: Oryza, 2009), 125.

22 T. Hani Handoko. Manajemen Personalia dan Sumberdaya Mausia. (Yogyakarta: BPFE-Yogyakarta, 1996), 193194.

23 Veithzal Rivai. Manajemen Sumber Daya Manusia untuk Perusahaan. (Jakarta: RajaGrafindo Persada, 2004), 475476.

24 Moh. As'ad, M. Psikologi Industri. (Yogyakarta: Liberty, 2004),115-116.

25 Alan M. Saks, "Antecedents and consequences of employee engagement," Journal of managerial psychology 21, no. 7 (2006): 600-619.

26 Cook, S. The essential Guide to Employee Engagement. (London: Kogan Page Limited, 2008).

27 Hewitt, A. Trends in Global Employee Engagement: Global Anxiety Erodes Employee Engagement Gains. (AON Hewitt, 2017), 2.

28 Garber, P.,R. 50 Activities for Employee Engagement. (Amherst: HRD Press. Inc, 2007),5-6.

29 Wise, D. Employee Engagement Leadership Workshop: Turning Employee Feedback into Results. (USA: DecisionWiseInc, 2010), 6.

30 Federman, B. Employee Engagement: A Road For Creating Profits, Optimizing Perfomance, And Increasing Loyalty. (San Fransisco: Jossey Bass, 2009), 44.

31 Thomas, K.,W. Instrinsic Motivation at Work: What Really Drives Employee Engagement. (San Fransisco: BerrettKoehler Publishers, 2007), 12.
} 
In the language of motivation theory, this is extrinsic appreciation. Extrinsic rewards do not originate from the work itself; they are distributed by supervisors to ensure that work is done correctly and rules are followed. They include compensation such as salaries, bonuses, commissions, benefits, and cash awards. Thomas, ${ }^{32}$ also stated that non-financial compensation is able to influence employee engagement as well as support from superiors or managers by providing opportunities for employees to meet face-to-face, talk, and share their passion/talents with each other, so that team members will be more easy to fill in the blanks. The support of a boss or manager will be able to complete the job better and the employees will feel comfortable working for the company, so that he/she will decide to stay at the company rather than having to move to another company.

Compensation has a positif relationship with employee engagement. Kurniawan and Nurtjahjanti, 33 showed that financial and non-financial compensations have positive influence to employee engagement. The study of Mauliate, ${ }^{34}$ analyzed the compensation strategy to employee engagement. The results of the study are (1) The application of employee salary multiplication is the first priority, giving employee incentives and rewarding are the second and third priorities. (2) Alternative choices based on priorities in the employee salary multiplication program are work performance appraisals. (3) Alternative choices based on priorities in employee incentives are financial incentives. (4) Alternative choices based on priority in reward giving are promotion of position.

The job satisfaction is also the determinant employee engagement. Wise, ${ }^{35}$ stated that many factors influencing the employee engagement are job satisfactions. It is a positive emotional condition or pleasant produced by the job or one's job experience. Moreover, Karangan, ${ }^{36}$ showed that the job satisfaction has affirmative effect on employee engagement. Lienardo and Roy,37 also showed that the job satisfaction influences the employee engagement. Lumbantoruan, ${ }^{38}$ conducted a study about the relationship of job satisfaction with employee engagement. The results of the study showed that there are positive and significant relationships between job satisfaction and employee engagement which means the higher employee job satisfaction, the higher employee engagement.

One of the objectives of granting such compensation is job satisfaction ${ }^{39}$. Providing compensation enables employees to meet all their physical, social status and selfish needs so that they get job satisfaction from their positions. Widodo, ${ }^{40}$ also conveyed the determinants of job satisfaction. One of the determinants of job satisfaction is salary or wages. Salary is a factor in fulfilling the life needs of employees who are considered appropriate or not. Mamik

\footnotetext{
32 Ibid, 155

33 Kurniawan dan Nurtjahjanti, "Hubungan Antara Persepsi Terhadap Kompensasi Dengan Employee Engagement Pada Karyawan PT. X."

34 E. Mauliate, "Analisis Strategi Kompensasi Terhadap Employee Engagement PT Bank Central Asia KCU Bogor [skripsi]," Bogor (ID): Institut Pertanian Bogor, 2015.

35 Wise, D. Employee Engagement Leadership Workshop: Turning Employee Feedback into Results. (USA: DecisionWiseInc, 2010), 6.

36 Cynthia Rachel Karangan, "PENGARUH KEPUASAN KERJA TERHADAP EMPLOYEE ENGAGEMENT TeLER DI PT. BANK NEGARA INDONESIA CABANG BANDUNG" (PhD Thesis, Universitas Widyatama, 2015).

37 Sylvia Lienardo, "Pengaruh Organizational Trust Dan Job Satisfaction Terhadap Employee Engagement Pada Karyawan Pt. Bangun Wisma Sejahtera," Agora 5, no. 1 (2017).

38 Erick Robson Lumbantoruan, "Pengaruh Kualitas Kehidupan Kerja, Kepuasan Kerja dan Komitmen Karyawan terhadap Kinerja Karyawan terhadap Kinerja Karyawan dan Prilaku Kewargaan sebagai Variabel Intervening (Studi pada PT. Perindustrian dan Perdagangan Crumb Rubber Pekanbaru)," Jurnal Online Mahasiswa Fakultas Ekonomi Universitas Riau 2, no. 1 (2015).

${ }^{39}$ Malayu S.P. Hasibuan. Manajemen Sumber Daya Manusia. (Jakarta: Sinar Grafika Offset, 2003), 121

40 Widodo, S.,E. Manajemen Pengembangan Sumber Daya Manusia. (Yogyakarta: Pustaka Pelajar, 2015)
} 
Eko Supatmi, et $\mathrm{al}^{41}$ showed financial and non-financial compensation affect job satisfaction. Etichasarie, et $\mathrm{al}^{42}$ also showed that non-financial compensation influences job satisfaction.

\section{Hypothesis}

$\mathrm{H}_{1}$ : $\quad$ Financial compensation directly influences employee engagement.

$\mathrm{H}_{2}$ : Non-financial compensation directly infuences employee engagement.

$\mathrm{H}_{3}$ : Job satisfaction influences employee engagement.

$\mathrm{H}_{4}$ : Job satisfaction mediates the effect of financial compensation on employee engagement.

$\mathrm{H}_{5}$ : Job satisfaction mediates the effect of non-financial compensation on employee engagement.

\section{METHOD RESEARCH}

Validity and reliability tests are used to test research instruments. This study was an explanatory study by using a quantitative approach with a path analysis method. The samples of this study were187 employees selected by a technique of proportional random sampling with 5 per cent precision. The data source in this study was through the structured questionnaire distribution of financial compensation variables, non-financial compensation, job satisfaction, and employee engagement by using a measurement scale in the form of a Likert scale. The Likert scale consists of five rating categories, namely strongly agree with a score of 5 , agree with a score of 4 , neutral with a score of 3 , disagree with a score of 2 , and strongly disagree with a score of 1 .

The first independent variable in this study was financial compensation (X1) which consists of indicators such as salary, incentives, and benefits. Furthermore, the second independent variable in this study was non-financial compensation (X2) which consists of indicators of promotion and work environment. The mediating variable in this study was job satisfaction $(\mathrm{Z})$. Indicators of the job satisfaction variable $(\mathrm{Z})$ were financial satisfaction, physical satisfaction, social satisfaction, and psychological satisfaction. Meanwhile, the dependent variable in this study was employee engagement. Indicators of employee engagement variables are say, stay, and drive. Data analysis employed path analysis.

\section{RESULTS AND DISCUSSION}

Based on table 1 can be described the identity of respondents. Characteristics of the respondents that were found previously were sex, age, level of education, length of work, status. By sex, they included $93 \%$ men and $7 \%$ women. Furthermore, based on marital status, there were $63 \%$ of respondents who were single and $37 \%$ were married. Furthermore, based on the latest level of education including scholarship amounting to $8.5 \%$, diploma amounting to $0.1 \%$, high school/vocational school totaling $88.8 \%$, junior high school totaling $1.1 \%$, and others $1.1 \%$. Furthermore, based on age which includes age under 21 years there are $10 \%$, 21-30 years there are $72 \%$, age 31-40 years there are $15 \%$, and age over 41 years there are $3 \%$. Based on the length of work covering a work period of less than 6 years, amounting to $80 \%$, a work period of 6-10 years totaling $13 \%$, working periods over 11 years totaling $7 \%$.

\footnotetext{
41 Mamik Eko Supatmi, Umar Nimran, dan Hamidah Nayati Utami, "Pengaruh pelatihan, kompensasi terhadap kepuasan kerja karyawan dan kinerja karyawan," PROFIT (JURNAL ADMINISTRASI BISNIS) 7, no. 1 (2013).

42 Recha Putrie Etichasarie, Bambang Swasto Sunuharyo, dan Yuniadi Mayowan, "Pengaruh Kompensasi Non Finansial Terhadap Kepuasan Kerja Dan Intention to Leave (Studi Pada Karyawan PT Pembangkitan Jawa Bali Unit Pembangkitan Gresik)," Jurnal Administrasi Bisnis 40, no. 2 (2016): 106-113.
} 
Table 1.

Biographical characteristics

\begin{tabular}{llll}
\hline Characterisctics & Variable Characteristics & Number & \% \\
\cline { 2 - 4 } Gender & Male & 173 & 93 \\
Marital Status & Female & 14 & 7 \\
& Married & 70 & 37 \\
Education & Single & 117 & 63 \\
& Informal school & 2 & 1.1 \\
& Secondary high school & 2 & 1.1 \\
& Senior High School & 166 & 88.8 \\
Age Group & Diploma & 1 & 0.5 \\
& Undergraduate degree & 16 & 8.5 \\
& Less than 21 years old & 19 & 10 \\
Experience & 21-30 years old & 136 & 72 \\
& 31-40 years old & 48 & 15 \\
& More than 41 years & 4 & 3 \\
& Less than 6 years & 150 & 80 \\
& 6-10 years & 24 & 13 \\
\hline
\end{tabular}

Validity test shows that the extent to which the data or instruments collected do not deviate from the description of the intended variable. The instrument is stated valid if the correlation coefficient $\geq 0.3$ with $\alpha=0.05$. The results of the validity test of each item statement of financial compensation variables, non-financial compensation, job satisfaction, and employee engagement show the correlation coefficient above 0.3 . These results indicate that the items of the four variables are valid. The reliability test measures instrument of accuracy (consistent). Cronbach's alpha value $(\alpha)>60 \%(0.6)$ indicates that the variable is reliable. Conversely, if the Cronbach's alpha value $(\alpha)<60 \%(0.6)$, then the variable has low reliability. The reliability test results of financial compensation variables (0.885), nonfinancial compensation (0.751), job satisfaction (0.866), and employee engagement (0.799) indicate the value of cronbach's alpha $(\alpha)>60 \%$. The reliability test results show that the four variables are reliable.

Table 2.

Means, correlatioans, reliabilities

\begin{tabular}{|c|c|c|c|c|c|c|}
\hline & Variables & Mean & 1 & 2 & 3 & 4 \\
\hline 1 & Financial compensation & 3.28 & $(0.885)$ & & & \\
\hline 2 & $\begin{array}{l}\text { Non-Financial } \\
\text { compensation }\end{array}$ & 3.68 & $0.465^{* *}$ & $(0.751)$ & & \\
\hline 3 & Job satisfaction & 3.37 & $0.613^{* *}$ & $0.537^{* *}$ & $(0.866)$ & \\
\hline 4 & Employee engagement & 3.43 & $0.556^{* *}$ & $0.467^{* *}$ & $0.683^{* *}$ & $(0.799)$ \\
\hline
\end{tabular}

Financial compensation has a positive correlation with employee engagement at a correlation value of 0.556 at a significance level of less than $1 \%$. Likewise, non-financial compensation has a positive correlation with employee engagement at a correlation value of 0.467 at a significance level of less than $1 \%$. Job satisfaction also has a significant positive correlation with employee engagement of 0.683 at a significance level of less than $1 \%$. 
Path analysis result shows that financial compensation has a significant positive effect on empoyee engagement of 0.197 with a probability value of 0.004 . This result illustrates the role of financial compensation as a determinant of employee engagement. As financial compensation increases, employee engagement also increases. However, non-financial compensation is not a determinant of employee engagement. The result of the path analysis shows that the effect of financial compensation has no effect on employee engagement, where the beta coefficient value is 0.102 and the probability is greater than $5 \%$. Job satisfaction has a significant positive effect on employee engagement of 0.507 with a probability level of 0.000 .

Table 3.

Path analysis

\begin{tabular}{|c|c|c|c|c|}
\hline & Coefficient & $\mathbf{T}_{\text {statistic }}$ & $P_{\text {value }}$ & $\begin{array}{l}\text { Indirect } \\
\text { effect }\end{array}$ \\
\hline $\begin{array}{l}\text { Financial compensation to employee } \\
\text { engagement }\end{array}$ & 0.197 & 2.929 & 0.004 & 0.235 \\
\hline $\begin{array}{l}\text { Non-Financial compensation to } \\
\text { employee engagement }\end{array}$ & 0.102 & 1.626 & 0.106 & 0.163 \\
\hline $\begin{array}{l}\text { Job satisfaction to employee } \\
\text { engagement }\end{array}$ & 0.507 & 7.182 & 0.000 & - \\
\hline $\begin{array}{l}\text { Financial compensation to job } \\
\text { satisfaction }\end{array}$ & 0.464 & 7.557 & 0.000 & - \\
\hline $\begin{array}{l}\text { Non-Financial compensation to job } \\
\text { satisfaction }\end{array}$ & 0.321 & 5.232 & 0.000 & - \\
\hline
\end{tabular}

The result of the path analysis shows a beta coefficient of 0.197 with a significance value of 0.004 . The result accepts the first hypothesis of this study. The first hypothesis proves the effect of financial compensation on employee engagement. The standardized coefficient beta value is positive indicating that financial compensation and employee engagement have a direct relationship. That is, the higher the financial compensation provided, the higher employee engagement will be. The results of this study are in line with research by Kurniawan and Nurtjahjanti 43 that financial compensation significantly influences employee engagement. Providing financial compensation to manufacturing companies can increase employee engagement. Especially in terms of timely payment of salaries, salaries are given in accordance with the position, duties and responsibilities carried. In accordance with the word of Allah in the Qur'an Surat Al-Jaatsiyah verse 22:

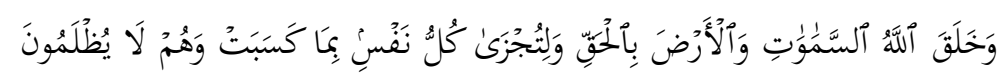

"Meaning; And Allah created the heavens and earth in truth and so that every soul may be recompensed for what it has earned, and they will not be wronged."

Giving employees the right to obligations that have been done must also be given in a timely manner, with no exception to financial compensation.

The second hypothesis in this study was not proven. Non-financial compensation does not significantly influence employee engagement. The path analysis result shows that the

43 Kurniawan dan Nurtjahjanti, "Hubungan Antara Persepsi Terhadap Kompensasi Dengan Employee Engagement Pada Karyawan PT. X." 
probability of non-financial compensation to employee engagement is 0.106 , greater than 0.05 , that is, non-financial compensation variables do not affect employee engagement in this manufacturing company. Company employees have not yet received a promotion in accordance with their tenure. The results of the descriptive analysis show that respondents' answers to the statement of promotion based on tenure are quite low. Therefore, companies need to provide promotions based on the length of service of employees. The results of this study differ from the theory conveyed by Thomas 44 that non-financial compensation is able to influence employee engagement as well as support from superiors or managers by providing opportunities for employees to meet face-to-face, talk, and share their passion/talents, so that team members will find it easier to fill in the gap. The support of a boss or manager will be able to complete the job better and the employees will feel comfortable working for the company, so that he will decide to stay at the company rather than having to move to another company.

The third hypothesis in the study also proved that job satisfaction has a significant and positive effect on employee engagement. The results of the analysis showed a beta coefficient of 0.507 with a significant value of 0.000 . Significantly positive value means that the higher the financial compensation provided, the higher employee engagement will be. Employee job satisfaction can also arise from a comparison of what is obtained with what other people have obtained. If the comparison is fair enough, then someone will feel job satisfaction. However, if the comparison is not fair there will be two possibilities, namely satisfaction if the employee feels disadvantaged and feels dissatisfied if he feels disadvantaged. As in the Qur'an the letter Al-Ma'arij verses 19-21 reads as follows;

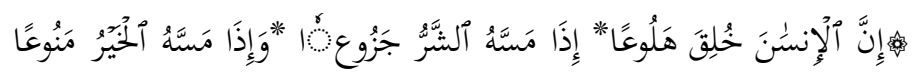

"Meaning; Indeed, mankind was created anxious; When evil touches him, impatient; And when good touches him, withholding [of it]."

Therefore, employees are encouraged to see and compare what they have gained with what has been obtained by people or their friends who are still at the bottom, so that they always feel grateful and satisfied for what has been obtained.

The fourth hypothesis in this study proved that job satisfaction mediates the effect of financial compensation on employee engagement. This analysis shows the value of the beta coefficient influence of financial compensation on employee engagement of 0.197 with a significance value of 0.004 , then the variable of financial compensation significantly and positively influences employee engagement. The standardized coefficient beta value indicates that the effect of job satisfaction on employee engagement is 0.507 with a significance value of 0.0005 , then the job satisfaction variable has a significant and positive effect on employee engagement. While the effect of financial compensation variables on employee engagement through job satisfaction amounted to 0.235 . That is, if more financial compensation and high job satisfaction, employee engagement will be higher as well. Vice versa, if low financial compensation is followed by low work satisfaction then the level of employee engagement is also low. The sobelt test results show a figure of 5.214>t-table of 1.984 which means that the variable job satisfaction succeeded in being a variable that mediated the effect of financial compensation on employee engagement. The results of this study prove that job satisfaction mediates the effect of non-financial compensation on employee engagement. The sobelt test results show a figure of 4.234 which indicates that the work satisfaction variable successfully

44 Thomas, K.,W. Instrinsic Motivation at Work: What Really Drives Employee Engagement. (San Fransisco: BerrettKoehler Publishers, 2007), 155. 
becomes a variable that mediates the effect of nonfinancial compensation on employee engagement.

\section{CONCLUSION}

Based on the results of research and discussion shows the variable financial compensation directly affects the employee engagement variable. Employees of these manufacturing companies get good salaries, incentives, and benefits, especially in terms of the timely delivery of salaries to employees. However, non-financial compensation does not directly affect the employee engagement variable. Job promotions do not yet reflect the aspirations of employees, namely promotions based on years of service. Job satisfaction variable has a positive and significant effect on employee engagement variables. Employees have experienced financial satisfaction, physical satisfaction, social satisfaction, and psychological satisfaction. Especially in terms of establishing good relations between supervisor/superiors with subordinates. Job satisfaction variable can be a mediator variable between financial compensation variable and employee engagement variable. This manufacturing company needs to pay attention to the length of service of employees as one of the judgments or considerations in carrying out promotions for employees because some employees feel that the implementation of promotions in accordance with their tenure has not been carried out properly. The existence of work tenure is one of the considerations in carrying out job promotions that will make employees stay in the company because they feel valued for their tenure.

\section{REFERENCES}

Anitha, J. "Determinants of employee engagement and their impact on employee performance." International journal of productivity and performance management 63, no. 3 (2014): 308.

Cook, S. The essential Guide to Employee Engagement. (London: Kogan Page Limited, 2008).

Etichasarie, Recha Putrie, Bambang Swasto Sunuharyo, dan Yuniadi Mayowan. "Pengaruh Kompensasi Non Finansial Terhadap Kepuasan Kerja Dan Intention to Leave (Studi Pada Karyawan PT Pembangkitan Jawa Bali Unit Pembangkitan Gresik)." Jurnal Administrasi Bisnis 40, no. 2 (2016): 106-113.

Fauzia, Mia Siti. "PENGARUH KOMPENSASI TERHADAP KEPUASAN KERJA PEGAWAI (Studi Persepsional Pegawai di PT. PLN (Persero) Kantor Distribusi Jawa Barat dan Banten)." PhD Thesis, Universitas Pendidikan Indonesia, 2015.

Federman, B. Employee Engagement: A Road For Creating Profits, Optimizing Perfomance, And Increasing Loyalty. (San Fransisco: Jossey Bass, 2009).

Garber, P.,R. (2007). 50 Activities for Employee Engagement. (Amherst: HRD Press. Inc, 20017).

Gonring, Matthew P. "Customer loyalty and employee engagement: an alignment for value." Journal of Business Strategy 29, no. 4 (2008): 29-40.

Harry, A. M. "Pengaruh Kompensasi, Status/Pengakuan, dan Kesempatan Berkembang terhadap Tingkat Employee Engagement pada Karyawan Universitas Sanata Dharma." PhD Thesis, Thesis Manajemen. Yogyakarta: Universitas Atmajaya, 2014.

Hewitt, A. Trends in Global Employee Engagement: Global Anxiety Erodes Employee Engagement Gains. (AON Hewitt, 2017).

Holbeche, Linda, dan Geoffrey Matthews. Engaged: unleashing your organization's potential through employee engagement. John Wiley \& Sons, 2012. 
Johnson, Jaime, Gary Cattermole, dan Diane Jackson. "Employee engagement creates a brighter economic future at Jupiter Hotels." Strategic HR Review 13, no. 2 (4 Februari 2014): 81-85. https://doi.org/10.1108/SHR-11-2013-0110.

Juan, Sui Hai, Liu Yao, Puteri Fadzline Binti, Muhamad Tamyez, dan Freida Ozavize. "KNOWLEDGE MANAGEMENT AND EMPLOYEE ENGAGEMENT." HAPPY READING, 2019.

Karangan, Cynthia Rachel. "PENGARUH KEPUASAN KERJA TERHADAP EMPLOYEE ENGAGEMENT TeLLER DI PT. BANK NEGARA INDONESIA CABANG BANDUNG." PhD Thesis, Universitas Widyatama, 2015.

Kari, Andi. "Pengaruh Kepuasan dan Motivasi Kerja terhadap Engagement Pegawai Tenaga Kependidikan di Politeknik Negeri Bandung." PhD Thesis, Universitas Pendidikan Indonesia, 2013.

Kurniawan, Briananta Winda, dan Harlina Nurtjahjanti. "Hubungan Antara Persepsi Terhadap Kompensasi Dengan Employee Engagement Pada Karyawan PT. X." Empati 5, no. 4 (2017): 732-737.

Lienardo, Sylvia. "Pengaruh Organizational Trust Dan Job Satisfaction Terhadap Employee Engagement Pada Karyawan Pt. Bangun Wisma Sejahtera." Agora 5, no. 1 (2017).

Lumbantoruan, Erick Robson. "Pengaruh Kualitas Kehidupan Kerja, Kepuasan Kerja dan Komitmen Karyawan terhadap Kinerja Karyawan terhadap Kinerja Karyawan dan Prilaku Kewargaan sebagai Variabel Intervening (Studi pada PT. Perindustrian dan Perdagangan Crumb Rubber Pekanbaru)." Jurnal Online Mahasiswa Fakultas Ekonomi Universitas Riau 2, no. 1 (2015).

Malayu S.P. Hasibuan. Manajemen Sumber Daya Manusia. (Jakarta: Sinar Grafika Offset, 2003).

Manik, DONATA ASMARANTA. "Pengaruh kualitas kehidupan kerja (quality of work life) dan kepuasan kerja terhadap keterikatan karyawan (employee engagement) di PT." Telekomunikasi Indonesia Tbk Witel Kalbar. Skripsi, tidak diterbitkan, Universitas Atma Jaya, Yogyakarta, 2015.

Mauliate, E. "Analisis Strategi Kompensasi Terhadap Employee Engagement PT Bank Central Asia KCU Bogor [skripsi]." Bogor (ID): Institut Pertanian Bogor, 2015.

Moh. As'ad, M. Psikologi Industri. (Yogyakarta: Liberty, 2004).

Muflih, Ikmal Nur. "Pengaruh Kompensasi Dan Motivasi Kerja Terhadap Kepuasan Kerja Karyawan Pt. Aseli Dagadu Djokdja.” Universitas Negeri Yogyakarta. Skripsi, 2015.

Mutiara S. Panggabean. Manajemen Sumber Daya Indonesia. (Jakarta: Ghalia Indonesia, 2004).

Paramartha, Althisa. "PENGARUH KOMPENSASI TERHADAP KEPUASAN KERJA KARYAWAN PADA PT GALAMEDIA BANDUNG PERKASA," 2013.

Popli, Sapna, dan Irfan A Rizvi. "Exploring the relationship between service orientation, employee engagement and perceived leadership style: a study of managers in the private service sector organizations in India." Journal of Services Marketing 29, no. 1 (23 Januari 2015): 59-70. https://doi.org/10.1108/JSM-06-2013-0151.

R. Wayne Mondy. Manajemen Sumber Daya Manusia Strategik. (Jakarta: Erlangga, 2008).

Saks, Alan M. "Antecedents and consequences of employee engagement." Journal of managerial psychology 21, no. 7 (2006): 600-619.

Supatmi, Mamik Eko, Umar Nimran, dan Hamidah Nayati Utami. "Pengaruh pelatihan, kompensasi terhadap kepuasan kerja karyawan dan kinerja karyawan." PROFIT (JURNAL ADMINISTRASI BISNIS) 7, no. 1 (2013).

Sutrisno, E. Manajemen Sumber Daya Manusia. (Jakarta: Kencana, 2012)

T. Hani Handoko. Manajemen Personalia dan Sumberdaya Mausia. (Yogyakarta: BPFEYogyakarta, 1996). 
Thomas, K.,W. Instrinsic Motivation at Work: What Really Drives Employee Engagement. (San Fransisco: Berrett-Koehler Publishers, 2007).

Triton, P.,B. Mengelola Sumber Daya Manusia. (Yogyakarta: Oryza, 2009).

Veithzal Rivai. Manajemen Sumber Daya Manusia untuk Perusahaan. (Jakarta: RajaGrafindo Persada, 2004).

Widodo, S.,E. Manajemen Pengembangan Sumber Daya Manusia. (Yogyakarta: Pustaka Pelajar, 2015).

Wise, D. Employee Engagement Leadership Workshop: Turning Employee Feedback into Results. (USA: DecisionWiseInc, 2010).

Wulandari, Nisa Ayu. "Pengaruh Kepemimpinan, Budaya Organisasi dan Kompensasi terhadap Keterikatan Karyawan (Studi Kasus Pada Bank Syariah Mandiri)." B.S. thesis, Jakarta: Fakultas Ekonomi dan Bisnis UIN Syarif Hidayatullah Jakarta, t.t. 